\title{
AZ IDŐSEBB GENERÁCIÓ MINT SEGÍTŐ AZ EGYSZÜLŐS CSALÁDOK ÉLETÉBEN
}

DOI: https://doi.org/10.53585/OnkSzem.2021.3.51-59

\section{Absztrakt}

Az Egyedülálló Szülők Klubja Alapítvány már a kezdetektől felismerte annak társadalmi hasznosságát, hogy az idősebb generáció az egyszülős családok életébe segítőként bevonható. A „Legyél a mi nagyink!” program ötlete abból a törekvésből indult ki, hogy az idősek és az egyszülősök csoportja könnyebben egymásra tudjon találni. A gyakorlatban azonban kiderült, hogy sokkal bonyolultabb az együttmúködés a szabad energiákkal rendelkező nyugdíjasok és a segítségre szoruló egyszülős családok között. A segítókész nagyik nem csupán gyerekfelügyeletet szeretnének vállalni, hanem igazán fontos számukra az érzelmi kötődés, a családhoz tartozás öröme. A pótnagyszülők pontosan tudják, hogy mennyivel többek, mint az egyszerű gyermekfelügyeletet vállaló bébiszitterek. Tapasztalataink szerint akkor működött a program, ha mindkét fél megkapta azt az érzelmi többletet, amire vágyott (családhoz tartozás) és közben hasznos segítséget nyújtott (törődés a gyermekkel). A bizalmi kapcsolatot sokkal könnyebb személyes formában, közös tevékenység során kialakítani, mint az online térben.

Kulcsszavak: szenior önkéntesség, egyszülős családok, bizalmi kapcsolatok, „Legyél a mi nagyink!” program

\section{The older generation as a helper, in the lives of single-parent families}

\section{Kriszta Hajas}

\section{Abstract}

From the very beginning, the Single Parents' Club Foundation recognized the social benefits of involving the older generation as a helper in the lives of single-parent families.

The idea of the "Be Our Grandma" program was based on an effort to make it easier for the groups of seniors and single parents to find each other. In practice, however, it has turned out that it was much more difficult for pensioners with free energies to help and work together with single-parent families. The helpful grandmothers not only want to take care of the children, but the joy of emotional attachment and belonging to the family is also very important to them. Substitute grandparents know exactly how much more they are than just babysitters who take care of a child. In our experience, the program worked when both parties have received the emotional surplus they wanted (belonging to a family) while providing practical help (caring for the child). It is much easier to build a relationship of trust personally, in a shared activity, than online.

Keywords: senior volunteering, single-parent families, relationships of trust, "Be Our Grandmother" Program

\footnotetext{
${ }^{1}$ Hajas Kriszta önkéntes koordinátor, Egyedülálló Szülők Klubja Alapítvány
} 


\section{BEVEZETÉS - AZ EGYSZÜLŐS KÖZPONT LÉTREJÖTTE}

Az Egyedülálló Szülők Klubja Alapítvány 2005-től segíti az egyedülálló szülőket azt vallva, hogy mind az egyedülálló szülőknek, mind az egyszülős családban felnövekvő gyerekeknek joguk van az egyenlő esélyekhez és lehetőségekhez. A kezdetektől egészen 2017-ig a gyermekeiket egyedül nevelő szülők érdekképviselete intézményi háttér nélkül szerveződött, de 2018-ban állami támogatással lehetővé vált, hogy létrejöjjön Budapesten, a nyolcadik kerületben az Egyszülős Központ, amit hamarosan követ a budai oldalon is egy újabb intézmény megnyitása. A központok segítő- és közösségi terek, amelyeknek célja, hogy lehetőségeket és esélyeket teremtsenek több mint félmillió egyszülős gyereknek, valamint támogató közegként - például programokkal, képzésekkel vagy különböző szakemberek hozzájárulásával - segítsék az egyszülős családok mindennapjait.

Az Egyedülálló Szülők Klubja Alapítvány életében mindig kiemelkedő szerepe volt az önkéntességnek. Az önkéntesek fontos szerepet játszottak a központ megalakulása után is, hiszen elengedhetetlen szerepük van a családoknak nyújtott szolgáltatásoknál, tanácsadásoknál, programoknál. Egy olyan családnál, ahol az egyik szülő hiányzik, számos területen jól jön a segítség: elég, ha a napi logisztikára gondolunk (gyerekeket óvodába, iskolába, edzésre vinni stb.).

Sok esetben a szülőpár mellett még a támogató nagyszülő is hiányzik, és ezt felismerve indult el a „Légyél a mi nagyink!” önkéntes segítő programunk 2017 februárjában. A következőkben bemutatom a program indulását, körülményeit, a szenior önkéntesek bevonását, motiválásának eszközeit és végezetül a program tanulságait, adaptálásának lehetőségeit.

\section{„LEGYÉL A MI NAGYINK!” - SIKERES ÖNKÉNTES SEGÍTŐPROGRAM AZ EGYSZÜLŐS KÖZPONTBAN}

Magától értetődőnek túnik, hogy valamilyen módon szükséges és érdemes összekötni a segítőkész, tettre kész idősebb korosztályt és az időhiánnyal küzdő, leterhelt egyszülős családokat. Az egyik oldalon van az idősebb, nyugdíjas generáció, aki egyre hosszabb életkort él meg. Sokan közülük szellemileg és fizikailag aktívak, tele vannak energiával. Vágynak az új emberi kapcsolatokra, közösségre és szeretnének társadalmilag hasznos tevékenységet végezni. A másik oldalon pedig ott van az egyszülősök széles tábora, akik valamilyen okból - 
válás, haláleset, örökbefogadás, egyedül vállalt terhesség stb. - egyszülős élethelyzetbe kerültek, ezért egyedül kell megoldaniuk a mindennapok terheit.

A „Legyél a mi nagyink!” program alapötlete tehát abból a felismerésből született, hogy ez a két csoport óriási segítsége lehet egymásnak, és az Egyszülős Központ koordinálja és lehetőséget adjon arra, hogy egymásra találjanak az idejüket és energiájukat szívesen felajánló nyugdíjasok, valamint a nagyszülői törődésre vágyó gyermeküket egyedül nevelő szülők.

Az ötlet még a központ épületének átadása előtt született, ezért az online kapcsolatfelvétel lehetőségére létrehoztunk egy felületet, ahova a családot kereső nagyik és a nagyit kereső családok regisztrálhattak. A program iránt érdeklődők feltölthették a saját magukat bemutató adataikat, elérhetőségüket, ami kiindulópont volt arra, hogy kivel lehet, vagy érdemes kapcsolatot felvenni mindkét oldalról.

Tapasztalataink szerint sok tényezőtől függ, hogy a kölcsönös levélváltások után létrejön-e személyes kapcsolat és sikerül-e bensőséges, bizalmi viszonyt kialakítani, ami feltétele annak, hogy a pótnagyi egy család részévé váljon. Noha a párok sorsát a kapcsolatfelvétel után nem követtük szorosan, de a pozitív visszajelzések mellett néhány esetben azt tapasztaltuk, hogy a jelentkezők elképzelései nem voltak mindig összhangban. Igen gyakran előfordult, hogy az egyszülősök elsősorban gyermekfelügyelethez kerestek segítséget, míg a pótnagyszülőnek jelentkezők közös beszélgetésekre, családi programokra vágytak. Ennek az igen értékes tapasztalatnak a birtokában fejlesztjük tovább a programot, hogy miként lehetne az offline térbe adaptálni.

\section{HOGYAN LESZNEK AZ IDŐSKORÚAK ÖNKÉNTESEK AZ EGYSZÜLŐS KÖZPONTNÁL?}

A legtöbb esetben a nyugdíjasok maguk jelentkeznek segítőnek. Amennyiben sikerül megtalálni, hogy milyen tevékenységben lesznek motiváltak, hosszú távú elkötelezettségre is számíthatunk. Aki elégedett és jól érzi magát segítőként, az szívesen megosztja örömét barátaival. Fontos kiemelnünk azt a tapasztalatunkat, hogy az idősebb generációból a legtöbb önkéntes a segítőink kapcsolati hálóján keresztül kerül az Egyszülős Központhoz.

Toborzással is próbáltuk bővíteni a szenior korú segítők táborát. A nyolcadik kerület környékbeli, idősek klubja tagjait meghívtuk, hogy megismertessük velük az Egyszülős Központ tevékenységét és azt a lehetőséget, hogyan tudnak segítőként a munkánkhoz kapcsolódni. $A$ programot a nyugdíjasok számára is vonzó, szórakoztató zenés-táncos műsorral egészítettük 
ki. Igyekezetünk azonban nem hozta a várt eredményt. A klubok idős tagjai - bár a szervezett programon szívesen részt vettek - a későbbiekben azonban nem mutattak aktivitást, a közel 50 résztvevőből csupán hárman érdeklődtek az önkéntes segítő tevékenység iránt.

Az Egyszülős Központ szenior önkéntesei két csoportra oszthatók. Az egyiket azok az időskorúak alkotják, akik meghatározott területen ajánlják fel önkéntességüket, míg a másik csoport azokból az „általános” önkéntesekből áll, akik főként a központ munkáját segítik, programjainak aktív résztvevői.

\section{SZENIOR ÖNKÉNTESEK, AKIK MEGHATÁROZOTT TERÜLETEKEN AJÁNLOTTÁK FEL SEGITSÉGÜKET}

A központ nemcsak általánosságban igyekezett segítő kezet nyújtani az egymás számára hasznos generációk egymásra találásában, hanem konkrét segítséget (például korrepetálást) felajánló önkénteseket is kiajánlott az egyszülősöknek. Az 1. táblázat adatai alapján egyrészt jól látható, hogy noha 2021-ben csökkent a tanárok száma, de a nyugdíjas tanároké nem változott, a tanárok összlétszámának 36 százalékát teszik ki a nyugdíjasok. Másrészt az is kiolvasható, hogy az idős korosztályhoz tartozó korrepetitorok száma nem változott a tavalyihoz képest, ennek ellenére idén fél év alatt dupla mennyiségű felzárkóztató órát tartottak. Ez abból adódik, hogy a pandémia idején online folyt a tanítás. Azáltal, hogy otthonról szervezték tanáraink az oktatást, az általuk önkéntes munkára szánt időkeretbe több tanítási óra fért bele.

1. táblázat Korrepetálási órák száma 2020-ban és a 2021 első félévében az Egyszülös Központban

\begin{tabular}{|c|c|c|}
\hline & $\mathbf{2 0 2 0}$ & 2021. június 30-ig \\
\hline Tanárok száma összesen & 23 & 19 \\
\hline Nyugdíjas tanárok száma & 7 & 7 \\
\hline Letanított órák száma összesen & 312 óra & 365 óra \\
\hline $\begin{array}{c}\text { Nyugdíjas tanárok által letanított } \\
\text { órák }\end{array}$ & 116 óra & 232 óra \\
\hline
\end{tabular}

Forrás: Egyszülös Központ nyilvántartása

A tapasztalataink azt bizonyították, hogy elmélyült, bizalommal teli kapcsolatok a közösen eltöltött tevékenység során könnyebben alakulnak ki. Az elmúlt években többször tanúi 
lehettünk közeli, igazi meghitt viszonyok kialakulásának az egyszülős családok és segítőik között. A közös tanítás-tanulás folyamatnál több példa is volt erre.

Magdi néni egykor tanító volt, és egy általános iskola köztiszteletben álló igazgató helyetteseként ment nyugdíjba. Elsők között jelentkezett segítőnek a korrepetálási programunkra. Egy nyolcéves kisfiú komoly olvasási nehézségekkel, helyesírási problémákkal és gyenge matematika eredménnyel került hozzá. „Szuper Magdi”, ahogy a kisfiú elnevezte korrepetáló tanítóját, 80 felé járt már, de rendíthetetlen derüvel és türelemmel foglalkozott két éven keresztül vele. A korábban gyengén teljesítő, zárkózott kisfiú negyedik év végén boldogan mutatta be jeles bizonyítványát. Magdi néni sajnos betegsége miatt nem vállal több tanítást, de azóta is tartják a kapcsolatot.

Márta néni matematika-fizika szakos gimnáziumi tanár volt, aki 67 évével friss nyugdijasnak számított. Saját bevallása szerint, az önkéntes tanítással szellemi frissességét akarta megörizni, és már három éve, a felzárkóztató programunk indulásától velünk van. Sok diák pótvizsga és érettségi felkészitésében segített. Imádja a kihívásokat, óriási teherbírása van. Amikor a járvány miatt nem folytatódhattak személyesen a korrepetálások, azonnal felajánlotta az online tanítás lehetőségét, hiszen a kényszerü karantén alatt nagymértékben megnövekedett az igény a tanulásban való segítségre és Mártára mindig lehetett számítani, egyszerre öt diákkal is foglalkozott. Az egyik tanítványával különösen szoros lett a kapcsolata, aki kivételesen nem gyerek, hanem két gyermekét egyedül nevelő szülő volt és felnöttfejjel határozta el, hogy a meglehetösen nehéz körülmények dacára leérettségizik. A 26 éves nö eröszakos férjétöl anyaotthonba menekült, ahonnan kemény munkával sikerült gyermekeivel együtt albérletbe költöznie, és hogy fenn tudja tartani családját, két munkahelyen is helytállt. Márta néni három éve követi az anyuka mindennapos küzdelmét és ahol tudja, segíti, legutóbb például kapcsolatai révén munkát is talált számára.

Erzsi néni és kis tanítványa is egy igazi sikertörténet. Egy évi közös tanulás után két jegyet javított a korrepetált kislány matematika eredményén. A közös munka alatt, úgy megszerették egymást, hogy idén nyáron Erzsi néni meghívta magához egy hétre a nyaralójába őt, anyukájával együtt.

A 78 éves Pali bácsi egy igazi finom, régivágású úriember. Végzettsége szerint mérnök, aki három évvel ezelőtt matematika- és fizika korrepetálásban ajánlotta fel segítségét, azóta is 
rendületlenül járnak hozzá tanítványok. A halk szavú, végtelenül türelmes, ugyanakkor határozott tanár úr népszerüségét az is mutatja, hogy nyáron is igénylik segítségét a diákok.

Egyszer személyesen jelentkezett pótnagyinak egy nyugdíjas tanárnő. Meginvitáltuk az éppen futó közösségépítő programunkra, hátha talál ott megfelelö családot. A rendezvényen meg is emlitette jövetele célját, amit a jelenlévő - az akkor önkéntesként pilatest oktató lány érdeklödéssel hallgatott. A legközelebbi óráján el is mesélte a tornázó anyukáknak, akik közül az egyik már régen szeretett volna egy kedves pótnagyit a lányának, ezért el is kérte a néni elérhetőségét. Így kezdődött egy hosszú távú gyümölcsöző kapcsolat, ami már két éve mindenki megelégedésére remekül funkcionál: közös kirándulásokkal, nyaralással.

A fentebb bemutatott tanulópárok példája is jól mutatja, hogy több generációnyi távolság ellenére is ki tudnak alakulni mély emberi kapcsolatok. A legtöbb esetben a bizalmi viszony létrejötte egy hosszú folyamat eredményeként valósult meg, de előfordulhatnak olyan szerencsés találkozások is, amikor már első alkalom után csodás összhang alakul ki.

\section{SZENIOR KORÚ „ÁLTALÁNOS” ÖNKÉNTESEK AZ EGYSZÜLŐS KÖZPONTBAN}

Fentebb olyan önkéntesek történeteit mutattam be, akiknek konkrét elképzelésük volt arról, hogy milyen segítő tevékenységet szeretnének nálunk végezni. Sokan vannak azonban olyanok is, akik bármilyen tevékenységgel szívesen támogatnának bennünket. Jelentkezésük után, ha mód van rá, személyes találkozón igyekszünk jobban megismerni a felajánlók erősségeit, kompetenciáit. Az így szerzett ismeret később sokat segít, ha majd egy meghatározott célhoz keresünk önkénteseket. Többször előfordult, hogy egy feladatra a legalkalmasabb jelölt pont az idősebb generációból került ki.

„Angyalok pedig léteznek” címmel hirdettük meg 2019. karácsony előtt azt a programunkat, amivel nehéz körülmények közt élő gyerekeknek szerettünk volna meglepetést szerezni. Legfőbb kívánságukat a kicsik lerajzolták és elküldték nekünk, amit FB oldalunkon nyilvánossá tettünk. Ezekből választhatták ki az önkéntesen adakozó „angyalok”, hogy melyiket teljesítik, és díszcsomagolásban juttatták el ajándékaikat, amit egy meghitt ünnepélyen a Mikulás osztott szét az Egyszülős Központban.

A Mikulás szerepre a bemutatkozó beszélgetés alapján nagyon alkalmasnak tünt Laci bácsi, aki korábban gyerekmüsorokat szerkesztett a TV-nél, és örömmel elvállalta a megbízatást, sőt 
komplett müsortervvel érkezett az ünnepségre. Kis versikék kíséretében adta át az ajándékokat az egybegyült csemetéknek.

Egy idös festömüvésznöröl a bemutatkozó beszélgetés során derült ki, hogy mostanában új hobbi tölti ki mindennapjait, gyönyörü nemez-képeket készít. Amikor felmerült a kérdés, hogy mit alkossunk a FICSAK által szervezett Adventi Jótékonysági Vásár, rögtön Ő jutott eszünkbe. Útmutatásai alapján aztán egy igazi csapatépitő workshop kerekedett, ahol a központ összes munkatársa színes nemez-ékszereket készített az eseményre.

Az egykor óvónőként dolgozó Éva néni a külföldön élő unokái hiányát szerette volna enyhíteni azzal, hogy jelentkezett nálunk önkéntes munkára. Örömmel vállalta el, a játszóház vezetőnk alkalmi helyettesitését annak kéthetes távolléte alatt.

A szenior korú „általános” önkéntesek közül kerülnek ki a családi rendezvények segítői is, mint például a Kálvária téren, 2019 augusztusában megrendezett a „Több, mint Egészség” elnevezéssel futó nagyszabású családi élménynapon is. Az idősebb korosztályból ketten is vállalkoztak, hogy részt vesznek az egész napos aktivitásban. A program címe is sejteti, hogy a kiemelt téma az egészségmegőrzés volt, amire szórakoztató eseményekkel hívtuk fel a figyelmet. Központi aktivitásnak a 7Próba játékot szántuk, aminek lényege az volt, hogy aki az egyes állomásokon teljesítette a hét próbát és begyűjtötte a hét pecsétet, a rendezvény alatt két nyereménysorsoláson is részt vehetett. Önkénteseink feladatához tartozott a játék ismertetése, illetve annak elvégzésének ellenőrzése. A központ munkatársaihoz hasonlóan ők is védőruhát (egyszülős pólót), védőitalt (két üveg ásványvizet) és hideg élelmet (két szendvicset) kaptak. Annak ellenére, hogy a nap végére bizony mindenki alaposan elfáradt, jókedvűen és elégedetten búcsúztunk el egymástól.

Nem csak Budapesten, az Egyszülős Központban igyekszünk bevonni a szenior korúakat az önkéntességbe, hanem például a klubhálózatunkhoz tartozó kecskeméti Egyszülős Klub is szoros kapcsolatot ápol nyugdíjasokkal. A klubvezető beszámolója szerint, kitűnően múködik az együttmúködés az idősebb generációból álló - CédrusNet - társadalmi innovációs program résztvevőivel, hiszen a társaság rendre meghívja rendezvényeire a helyi egyszülős közösséget. A kifejezetten ismerkedés céljából megrendezett „Pikniket”, a kerékpárok helyes karbantartásáról szóló, Majd a „Papa megmutatja” néven futó program követte. A közös madáretető építés is jó példa volt arra, hogy a generációs korkülönbség ellenére is kialakulhat jó együttműködés. 


\section{HOGYAN TUDJUK MEGTARTANI ÉS MOTIVÁLNI A SZENIOR KORÚ ÖNKÉNTESEKET?}

Az igaz, hogy az önkéntesek nem pénzért tevékenykednek, de az nem igaz, hogy minden „ellenszolgáltatás” nélkül ajánlják fel segítségüket. Motiváló tényezők közt szerepel a közösséghez tartozás öröme, a hasznosság érzése, személyes kapcsolatok szélesítésének igénye, a szabadidő értelmes eltöltése. Igénylik a munkájukkal kapcsolatos visszacsatolást, fontos számukra, hogy az adott tevékenységben jól érezzék magukat és elismerést, figyelmet kapjanak. Az önkéntesek felé tett gesztusoknak az a jelzésértéke, hogy a szervezet fontosnak tartja a munkájukat.

A megtartásuk szempontjából legfontosabb tehát a személyes kapcsolattartás, érdeklődés, odafigyelés, pozitív megerősítés, állandó visszajelzés, dicséret, igényeik figyelembevétele. Olyan hétköznapi gesztusok, mint például a korrepetálás előtt egy kancsó víz bekészítése is, sokat jelenthet számukra.

Az idősebb korosztály számára különösen fontos az előre tervezhetőség, kiszámíthatóság, ezért megnyugtató számukra a megbízható koordinálás, hogy a vállalt feladatukat rendezett környezetben végezhetik.

Szervezeti szinten is jó, ha minden az önkéntesség megbecsültségét közvetíti. Ilyenek lehetnek: az önkéntesek számára rendezett éves rendezvények, munkájuk nyilvános megköszönése, díjazás, kis ajándékok. Apró figyelmességek, mint például a szervezet kiemelt programjaira személyes meghívó küldése, is erősíti kötődésüket a szervezethez.

Érdemes bevonni az önkénteseket a média-megjelenésekbe is. Sokan szívesen megnyilvánulnak nyilvánosan is. Nagyon pozitív megerősítés, ha valaki az alapítványnál végzett munkájáról a nagy nyilvánosság előtt beszélhet.

A kommunikációs felületeken is fontos hangsúlyozni a pro bono munka társadalmi hasznosságát. Jó ötlet például a ledolgozott munkaóráról összesített kimutatásokat publikálni. Lehetőségeinkhez mérten kedvezményeket is felajánlunk segítőinknek. Ebből a célból vezetjük be a támogatói kártyát, amivel a pro bono alapon hozzánk kapcsolódók egyszülős kedvezményeket vehetnek igénybe. 


\section{ÖSSZEGZÉS}

$A z$ idősebb generációhoz tartozó segítőkkel együtt töltött közös munka megerősített bennünket abban, hogy lehet a nyugdíjas korosztály tapasztalataira számítani és érdemes további lehetőségeket keresni a különböző nemzedékek közötti kapcsolat megerősítésére. Az idősek és egyszülősök csoportjára egyaránt jellemző az elszigetelődés, éppen ezért nagyon jól ki tudnák egészíteni egymást. Az idősek bekapcsolása az önkéntes tevékenységbe mindkét fél számára kölcsönös haszonnal jár. A segítő tevékenység révén a nyugdíjas generációnak lehetősége van, hogy társadalmilag aktív maradjon, a gyermeküket egyedül nevelő szülők pedig általuk - bizonyos területeken legalább - enyhíteni tudják a másik szülő hiányát. 